\title{
A survey on the effects of knowledge management on organizational learning: A case study of technical and vocational training organization
}

\author{
Naser Azad ${ }^{a^{*}, E}$ Esmaeil Mehrabi Majolan ${ }^{\mathrm{b}}$ and Vahid Peej
}

${ }^{a}$ Department of Management and Accounting, South Tehran Branch, Islamic Azad University, Tehran, Iran

${ }^{b}$ Department of Management, Islamic Azad University, Science and Research Branch, Iran

${ }^{c}$ Department of Management, Islamic Azad University, Arak Branch, Arak, Iran

\section{CHRON I C L E}

Article history:

Received July 28, 2013

Received in revised format

20 November 2013

Accepted 4 January 2014

Available online

February 162014

Keywords:

Knowledge management

Organizational learning

Focus strategy

Relationship-oriented marketing

\section{A B S T R A C T}

This paper presents an empirical investigation to study the effects of knowledge management on organizational learning. The study is held in headquarter of technical and vocational training organization in city of Tehran, Iran. The proposed study measures the effects of concept of management, management, knowledge tools, measurement, change management and knowledge content on organizational learning. The study designs a questionnaire in Likert scale and selects a sample of 313 people randomly from 1680 people who work for this organization in city of Tehran, Iran. Using structural equation modeling, the study has detected a positive and meaningful relationship with knowledge management on organizational learning. In our survey, knowledge content is the most important factor followed by change management.

\section{Introduction}

Knowledge playas essential role on the success of organizations and knowledge management (KM) is the key component of business development (Nonaka, 1991, 1995; Collinson \& Cook, 2007; Van Grinsven \& Visser, 2011). Darroch (2005), for instance, provided important empirical evidence to support the role of KM within firms. The author presented knowledge management as a coordinating mechanism and provided some evidence to support the view that a firm with a knowledge management capability could use resources more efficiently. Lustri et al. (2007) presented a KM conceptual framework for competency development and a case study in a law service firm, which applied the KM model in a competencies development program.

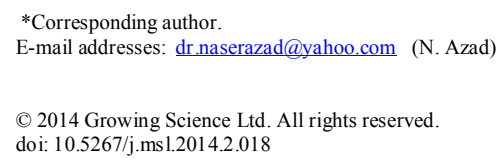


Monavvarian, and Kasaei (2007) studied the impact of organizational elements and the performance of knowledge management. They identified seven main independent variables including organizational culture, organizational structure, technology, human resources, transparency of documents, flow of information and communication, and training and they were examined against creation, dissemination and store of knowledge, together with implementation of KM based on the multi-variable regression test. They reported that four of the independent variables influenced on the cycle of KM. Although only some of the independent variables influenced on the effective management of knowledge, other variables must be also considered, as they are still very important for some organizations.

Ray (2008) provided a roadmap for firms to implement a KM system that reduces loss of critical information and improves data retrieval. The study provided information for describing information sources and simplifying data retrieval and recognized the necessity to collect and to retain corporate information through cooperation of knowledge workers. Raub and Von Wittich (2004) stated that successful implementation of knowledge management need to align the contributions of key organizational actors, to promote the development of knowledge networks and to provide necessary support by delivering a purposeful message.

Azad and Majolan (2012) performed a study on the impacts of KM on organizational entrepreneurship in a case study of educational system. They reported that knowledge content was number one priority followed by knowledge tools and concept of knowledge. The other factors including management, knowledge measurement and change management were in lower levels of importance. Garcia-Morales et al. (2007) investigated the effects of personal mastery on organizational performance, both directly and indirectly through the dynamic capabilities of organizational learning and innovation. They reported that in both types of firms personal mastery affected organizational performance directly and indirectly through organizational learning and innovation. In addition, organizational learning affected organizational performance positively, both directly and indirectly through organizational innovation and finally organizational innovation affected organizational performance positively.

\section{The proposed study}

This paper presents an empirical investigation to study the effects of knowledge management on organizational learning (Huber, 1991; Lam, 2001; Jerez-Gómez et al., 2005). The study is held in headquarter of technical and vocational training organization in city of Tehran, Iran. Technical and Vocational Training Organization (TVTO) is affiliated with Ministry of Labor and Social Affairs (MOLSA) and it was founded in 1980 by integrating three training bodies- MOLSA's General Directorate for Vocational Trainings, Apprenticeship Fund and Apprenticeship Society - as Technical and Human Force Training Organization. In 1981 the organization was renamed as Technical and Vocational Training Organization. TVTO is considered as the main institution in charge of short-term Technical and Vocational Trainings. It is also the Head of Special Committee on informal Technical and Vocational Training with 16 members from different ministries, organizations; Employee \& Employer Associations. TVTO implements its trainings through both public and private sectors.

TVTO's primary task is to provide vocational training and research through 1-18 months courses in: permanent centers of the public sector located in 600 centers- nationwide, mobile training teams in remote areas, training in prisons, training in garrisons, training in industries, training in Instructor Training Center (ITC) and private training institutions in14 thousand institutions authorized by TVTO. TVTO trains skilled and semi-skilled labor force needed by industry, agriculture and service providers throughout the country, and improves the culture of getting technical skills in the society. The proposed study measures the effects of concept of management, management, knowledge tools, 
measurement, change management and knowledge content on learning. The sample size of this survey is calculated as follows,

$$
n=\frac{N \times z_{\alpha / 2}^{2} \times p \times q}{\varepsilon^{2} \times(N-1)+z_{\alpha / 2}^{2} \times p \times q},
$$

where $N$ is the population size, $p=1-q$ represents the yes/no categories, $z_{\alpha / 2}$ is CDF of normal distribution and finally $\varepsilon$ is the error term. Since we have $p=0.5, z_{\alpha / 2}=1.96$ and $N=1680$, the number of sample size is calculated as $n=313$. The proposed study of this paper uses factor analysis to measure the effects of various components. The results of KMO test yields 0.957 and Bartlet test has been executed to validate the survey, where the Chi-Square is 5859.187 with $\mathrm{df}=406$ and Sig. $=$ 0.000 . These results confirm the overall questionnaire and we can confirm the overall survey. In other words, there is a strong correlation from one side with other variables but such relationship does not exist from the other side. We first consider the factor analysis on some raw data and Table 1 shows details of our findings.

\section{Table 1}

The preliminary results of factor analysis

\begin{tabular}{lcccc}
\hline Factor & $\begin{array}{c}\text { Non-standard } \\
\text { coefficient }\end{array}$ & $\begin{array}{c}\text { Standard } \\
\text { coefficient }\end{array}$ & t-value & Rank \\
\hline Knowledge concept & 0.61 & 0.91 & 20.73 & 3 \\
Management & 0.66 & 0.91 & 20.70 & 4 \\
Knowledge tools & 0.61 & 0.87 & 19.37 & 5 \\
Knowledge measurement & 0.32 & 0.78 & 16.21 & 6 \\
Change management & 0.42 & 0.94 & 21.97 & 2 \\
Knowledge content & 0.69 & 0.94 & 22.26 & 1 \\
\hline
\end{tabular}

Based on the results of Table 1, all components of knowledge management are statistically significance and we can use the results for the proposed study. Table 2 demonstrates details of the implementation of factor analysis on different questions of each six factors.

Table 2

The summary of the results of factor analysis

\begin{tabular}{|c|c|c|c|c|c|c|c|}
\hline Factor & Q. & Loading factor & t-value & Factor & Q. & Loading factor & t-value \\
\hline \multirow{3}{*}{$\begin{array}{c}\text { Knowledge } \\
\text { concept }\end{array}$} & 1 & 0.71 & 14.28 & \multirow{3}{*}{$\begin{array}{l}\text { Knowledge } \\
\text { measurement }\end{array}$} & 16 & 0.74 & 14.47 \\
\hline & 2 & 0.73 & 14.75 & & 17 & 0.78 & 15.5 \\
\hline & 3 & 0.70 & 14.01 & & 18 & 0.75 & 14.73 \\
\hline \multirow{7}{*}{ Management } & 4 & 0.70 & 14.17 & \multirow{7}{*}{$\begin{array}{c}\text { Change } \\
\text { management }\end{array}$} & 19 & 0.76 & 15.63 \\
\hline & 5 & 0.66 & 13.11 & & 20 & 0.70 & 14.23 \\
\hline & 6 & 0.70 & 14.01 & & 21 & 0.69 & 13.78 \\
\hline & 7 & 0.66 & 13.07 & & 22 & 0.70 & 14.09 \\
\hline & 8 & 0.53 & 10.05 & & 23 & 0.74 & 15.25 \\
\hline & 9 & 0.70 & 13.97 & & 24 & 0.71 & 14.39 \\
\hline & 10 & 0.66 & 12.94 & & & & \\
\hline \multirow{5}{*}{$\begin{array}{c}\text { Knowledge } \\
\text { tools }\end{array}$} & 11 & 0.74 & 14.83 & \multirow{5}{*}{$\begin{array}{l}\text { Knowledge } \\
\text { content }\end{array}$} & 25 & 0.75 & 15.55 \\
\hline & 12 & 0.71 & 14.05 & & 26 & 0.72 & 14.74 \\
\hline & 13 & 0.63 & 12.01 & & 27 & 0.72 & 14.73 \\
\hline & 14 & 0.64 & 12.31 & & 28 & 0.72 & 14.50 \\
\hline & 15 & 0.71 & 14.05 & & 29 & 0.61 & 12.07 \\
\hline
\end{tabular}

\section{Discussion and conclusion}

In this paper, we have presented an empirical investigation to study the effects of knowledge management on organizational learning in one of Iranian training centers. Our results have indicated 
that knowledge content plays essential role on the success of the organization. In addition, change management was the second most important factor for contributing in organizational learning. Knowledge concept was the third important factor affecting organizational learning. Our results are somewhat consistent with the results presented earlier by other researchers.

\section{Acknowledgement}

The authors would like to thank the anonymous referees for constructive comments on earlier version of this paper.

\section{References}

Azad, N., \& Majolan, E. (2012). A study on effects of knowledge management on organizational entrepreneurship: A case study of educational system. Management Science Letters, 2(8), 2711 2716.

Collinson, V., \& Cook, T. F. (2007). Organizational learning: Improving learning, teaching, and leading in school systems. Sage Publications.

Darroch, J. (2005). Knowledge management, innovation and firm performance. Journal of Knowledge Management, 9(3), 101-115.

Garcia-Morales, V. J., Lloréns-Montes, F. J., \& Verdú-Jover, A. J. (2007). Influence of personal mastery on organizational performance through organizational learning and innovation in large firms and SMEs. Technovation, 27(9), 547-568.

Huber, G. P. (1991). Organizational learning: The contributing processes and the literatures. Organization science, 2(1), 88-115.

Jerez-Gómez, P., Céspedes-Lorente, J., \& Valle-Cabrera, R. (2005). Organizational learning and compensation strategies: evidence from the Spanish chemical industry. Human Resource Management, 44(3), 279-299.

Lam, Y. J. (2001). Toward reconceptualizing organizational learning: a multidimensional interpretation. International Journal of Educational Management, 15(5), 212-219.

Lustri, D., Miura, I., \& Takahashi, S. (2007). Knowledge management model: practical application for competency development. Learning Organization, 14(2), 186-202.

Monavvarian, A., \& Kasaei, M. (2007). A KM model for public administration: the case of Labour Ministry. VINE, 37(3), 348-367.

Nonaka, I. (1991). The knowledge-creating company. Harvard business review,69(6), 96-104.

Nonaka, I. (1995). The Knowledge-Creating Company: How Japanese Companies Create the Dynamics of Innovation: How Japanese Companies Create the Dynamics of Innovation. Oxford university press.

Ray, L. L. (2008). Requirement for knowledge management: business driving information technology. Journal of Knowledge Management, 12(3), 156-168.

Raub, S., \& Von Wittich, D. (2004). Implementing knowledge management: Three strategies for effective CKOs. European Management Journal, 22(6), 714-724.

Van Grinsven, M., \& Visser, M. (2011). Empowerment, knowledge conversion and dimensions of organizational learning. Learning Organization, 18(5), 378-391. 